\title{
ISLAMSKA PERCEPCIJA FENOMENA SMAKA SVIJETA
}

\section{Sažetak}

Smak svijeta ili Kijametski dan bio je $i$ ostao fenomen koji je uvijek pobudivao maštu kod mnogih ljudi u svim generacijama, a posebno u posljednje vrijeme, kada se to pitanje $i$ medijski itekako aktualiziralo.

Mnogi su, osvríuci se na kalendar starih Maja na temelju kojeg se svijet završava 21. decembra 2012. godine, razumjeli da će tada i nastati Smak svijeta, pa je ovaj tekst doprinos boljem razumijevanju ovog fenomena.

Ovaj tekst tretira ovaj fenomen i iznosi njegovu islamsku percepciju sa bitnim detaljima koji ga pokušavaju približiti ljudskom poimanju, spominje temeljnu podjelu simptoma ovoga fenomena $i$ navodi po jedan primjer malog $i$ velikog njegovog predinaka.

Ključne riječi: Smak svijeta, mali predznaci, veliki predz̨naci.

\section{Uvod}

Pojam apokaliptičnog postao je simbolom Kraja svijeta ili vremenskog intervala pred Smak svijeta. On će, prema mišljenjima i predviđanjima nekih, biti obilježen strašnim pojavama, ogromnim udarima mora, rušenjem planina, pucanjem tla, požarom s neba...

Prema mnogim predviđanjima - poplave, zemljotresi, "cunamiji", velike suše, erupcije super vulkana, lude vođe, rat, nuklearno naoružanje, udar meteora, sunčeva super oluja, promjena magnetskih polova zemlje, drastična promjena klime, smrtonosni toksini, globalna epidemija - sve su to pojave i fenomeni koje bi u nekom drastičnom scenariju mogle biti realno opasne za preživljavanje čovječanstva i koje bi mogle teorijski prouzrokovati Apokalipsu.

Tako ekološka kriza personificirana u nestašici vode i razaranju okoliša, preko opasnosti nanotehnologije i umjetnih bolesti, do kataklizme novog ledenog doba ili pada u crnu rupu, svakoga treba navesti na angažiranije razmišljanje i duboko ga zabrinuti.

\footnotetext{
${ }^{1}$ Islamski pedagoški fakultet Univerziteta u Zenici.
} 
Drevna civilizacija Maja nestala je sa zemlje 500 godina prije otkrića Amerike, a iza sebe je ostavila niz zagonetki i enigmi. Jedna od najvažnijih je njihov ritualno-kosmički kalendar koji još uvijek fascinira savremenike svojom tačnošću i preciznošću.

Prema ovom kalendaru Maja, era tzv. Petog Sunca u kojoj čovječanstvo egzistira danas, završava se 21. 12. 2012. godine. $\mathrm{Na}$ temelju ove činjenice, zapadnjačka civilizacija je ustanovila brojne hipoteze prema kojima se Smak svijeta trebao dogoditi 2012. godine.

Čak je i najpoznatiji među onima koji su proricali budućnost, Nostradamus, čije su se prognoze u posljednjih 400 godina (uglavnom) ostvarivale, najavio Smak svijeta do kraja 2012. godine.

Nostradamus je najavio čudan kosmički fenomen, najvjerovatnije asteroid koji će dovesti do niza prirodnih katastrofa, erupcije svih vulkana na zemlji, kao i pojave "cunamija", tornada i zemljotresa. Promjenom polova Zemljina kugla bi stala, a onda bi počela da se okreće na drugu stranu oko svoje ose, što bi dovelo do toga da Sunce izlazi na zapadu, a zalazi na istoku.

O ovom fenomenu govorio je čak i Ajnštajn, koji je smatrao da je promjena polova Zemljine kugle sasvim mogući scenarij kraja čovječanstva.

Tumačeći Nostradamusova proročanstva, savremeni stručnjaci smatrali su da je moguć Treći svjetski rat u novembru 2012. godine u kojem je trebalo doći do upotrebe hemijskog i biološkog oružja, kao i sukob između Evrope i SAD-a, te između Velike Britanije i Francuske. Najavljivana je, za kraj 2012. godine, tragedija u Rimu i veliki sukob Amerike sa Iranom i Sjevernom Korejom.

Nostradamus predviđa kako će se veliki sukobi vrtjeti, uglavnom, oko nuklearnog oružja i to najviše na području Mediterana. Jedna atomska bomba će, prema njegovim predviđanjima, umjesto na kopno, pasti u more i pobiti sav podvodni svijet na tom području.

Prema njegovim predviđanjima, ništa bolja sudbina ne očekuje ni SAD. Osim prirodnih katastrofa, Nostradamus im predviđa građanske ratove, političke konflikte, očaj i naglo siromaštvo. 


\section{Islamska percepcija ovog fenomena}

Allah Uzvišeni jasno govori u Svojoj Knjizi:

„Pitaju te o Smaku svijeta kada će se zbiti. Reci: „To zna jedino Gospodar moj, On će ga u njegovo vrijeme otkriti, a tě̆ak ce biti nebesima $i$ Zemlji, sasvim neočekivano će vam doci". Pitaju te kao da ti o njemu nešto znaš. Reci: „To samo Allah zna, ali većina ljudi ne zna"."

„Ljudi te pitaju o Smaku svijeta, reci: „To jedino Allah zna! A ti ne znas,, možda je Smak svijeta blizu!" 3

„Pitaju te o Smaku svijeta: „Kada cé se dogoditi?" Ti ne znaš, pa kako da o пјети z̧boris, o njemu samo Gospodar tvoj zna."

Allahovi poslanici nisu znali kada će nastupiti Smak svijeta. Abdullah b. Mes'ud, r.a., prenosi da je Allahov Poslanik, s.a.v.s., rekao: „U noći Isra'a, sreo sam se sa Ibrabimom, Musaom i Isaom. Spominjali su Smak svijeta, pa su pitanja uputili Ibrabimu, na što je on rekao: "Ja o tome ništa ne znam!" Nakon toga su upitali Musaa, a on je odgovorio: „Ja o tome nista ne znam!" Napokon su upitali Isaa, pa je odgovorio: "Sto se tice njegove neizbje:̌nosti, to niko drugi, osim Allaba, ne zna, kao i o tome kada će me Allab obavijestiti da se pojavio

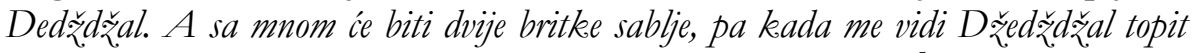
će se, kao što se olovo topi. Potom ce ga Allah Uquišeni unistiti!" "5

O tačnom nastupanju Smaka svijeta ništa nije znao ni Allahov Poslanik, s.a.v.s., ali ni najodabraniji melek - Džibril. To se jasno nazire iz onog dugog hadisa o imanu, islamu i ihsanu, u kojem Poslanik, s.a.v.s., na pitanje Džibrila o nastanku Kijametskog dana, jasno konstatira: „Ništa upitani ne zna više od onoga koji ga pita! "

Allah Smak svijeta naziva i Jevmu-l-arifeti/Dan bliski, zbog njegove blizine i bliskosti, a u kojem će, od straha i iznenađenja, srca do grkljana doprijeti: „I upozori ith na bliski Smak svijeta, kada će srca do grkljana doprijeti $i$ popriječiti se!"

\footnotetext{
2 El-A'raf, 187.

3 El-Ahzab, 63.

4 En-Nazi'at, 42-44.

5 Hadis bilježi Ahmed u svom Musnedu, 5/189. Ahmed Šakir tvrdi da je ova Ahnmedova predaja pouzdana!

${ }^{6}$ Muslim.

${ }^{7}$ El-Mu'min, 18.
} 
Dakle, o njegovom iznenadnom nastupanju ne zna niko - izuzev Gospodar svjetova, koji to posebno i ističe u ovom ajetu: „Smak svijeta se približava, Allah ce ga jedini otkeriti!" 8

Bliskost Smaka svijeta je u tome što je on stalno sve bliži, a to se eksplicite i vidi na temelju brojnih predznaka koji se sve više i više pokazuju i realiziraju.

Treba napomenuti da su veliki predznaci Smaka svijeta spomenuti i u Kur'anu i u sunnetu, dok je veliki broj malih predznaka spomenut u brojnim autentičnim Poslanikovim, s.a.v.s., predskazanjima. Obzirom da i Kur'an i sunnet tretiraju ovaj fenomen, onda nam postaje sasvim jasno da je to važna činjenica koju vjernici treba da uvažavaju i o tim nagovještajima razmišljaju.

Dovoljno je kazati da se nekoliko stotina vjerodostojnih hadisa bavi malim ili velikim predznacima Smaka svijeta što upućuje na istinsku važnost i značaj, jer Allah i Poslanik, s.a.v.s., govore o onom što je važno za čovjeka i cjelokupan ljudski rod.

Iako, prema islamskom poimanju ovog fenomena, niko ne zna kada će se on odigrati, ipak su o njemu pisali i govorili svi islamski umovi u prošlosti, ali i danas. Svi oni smatraju da, analizirajući taj događaj, mi iznjedrujemo brojne pouke i poruke koje emaniraju iz samoga nagovještaja takvoga događaja.

\section{Stvarna korist od vjerovanja u ovaj fenomen i njegove predznake}

Šta, ustvari, dobivamo našim vjerovanjem u ovaj fenomen i poznavanjem detalja koji nagovještavaju konačan nestanak ovoga svijeta? Śta dobivamo sa posljednjim velikim predznakom koji nedvojbeno nagovještava spuštanje zavjese na pozornici ovoga svijeta?

Neki islamski autori naveli su brojne koristi koje njedri ovaj fenomen, kao i simptome koji ga nagovještavaju. Između ostalih, to su:

- Potvrđivanje vjerovanja u transcendentalni svijet ili svijet gajba, svijet nevidljivoga i neopipljivoga, što predstavlja jedan od šest temelja cjelokupnog islamskog učenja. Allah Uzvišeni na početku najdulje sure u Kur'anu definira iskrene vjernike i govori kakvi oni treba da budu: „onima

${ }^{8}$ En-Nedžm, 57-58. 
koji u nevidliivi svijet budu vjerovali"! ${ }^{9}$ Naime, vjerovanje u još nevidljive preznake Smaka svijeta (pojava Isa, a.s., pojava Dedždžala, izlazak Je'džudža i Me'džudža, izlazak misteriozne Životinje koja će govoriti, sasvim neobičan i ljudskoj logici oprečan zakon pojavljivanja Sunca sa zapada i brojna druga Vjerovjesnikova, s.a.v.s., predviđanja spomenuta u autentičnim predanjima) jasno potvrđuje naše čvrsto vjerovanje u nevidljivi svijet.

- Vjerovanje u Smak svijeta i poznavanje njegovih predznaka vjerniku još više jača vjeru i razvija svijest o Sudnjem danu i važnosti pripreme za taj dan, a nemarne i grješne potiče da se prenu iz nemara $i$ utonuća u grijehe, da se vrate pokajanju svome Gospodaru i odupru se ovosvjetskim nasladama i raznim vrstama delikata.

- Konkretna korist poznavanja detalja predznaka Smaka svijeta osposobljava nas da prepoznamo opasnost koja nam prijeti sa nekim od njih, u smislu da se odupremo iskušenju koje će vjernike zadesiti njihovim pojavljivanjem. Tako će, primjera radi, vjernici umjeti prepoznati Dedždžala i njegovo zavođenje i neće se dati uhvatiti u njegovu mrežu u koju će uhvatiti sve one koji ne budu svjesni ko je on i koji ne budu poznavali njegov opis, karakteristike i brojne vještine kojima će zavoditi ljude u zabludu, tako da će ga mnogi smatrati i bogom. Naravno, kada ništa od toga ne bismo znali, zapali bismo u brojne dileme i probleme koji bi nas koštali možda čak i vjere.

- Brojni predznaci Smaka svijeta i detalji vezani za njih uveliko otvaraju vrata nade ljudima, jer se iz poznavanja tih predznaka spoznaje da budućnost pripada islamu koji će se izuzetno brzo širiti, a sve druge ideje i ideologije, pa i religije će stagnirati a njihova učenja devalvirati i, na koncu, nestati!

- Vjerovanje u fenomen Smaka svijeta i znanje o njegovim predznacima zasićuje radoznalost koja emanira iz svake osobe, a manifestira se u težnji da se sazna šta će se desiti u budućnosti, pogotovo što ti nagovještaji nisu produkt nečijih nagađanja ili nesigurnih predviđanja, nego stvarne istine, zasnovane na Allahovoj Knjizi i sigurnim i provjerenim Vjerovjesnikovim, s.a.v.s., predanjima.

- Predznacima koji su najavljeni savršenim kur'anskim ajetima i sigurnim Poslanikovim, s.a.v.s., predanjima, a pogotovo onim koji su se

${ }^{9}$ El-Bekare, 3. 
već ostvarili, minimiziraju se i neutraliziraju najave raznih lažljivaca koji tvrde da poznaju budućnost. Astrolozi, vračare, gatare, sihirbazi i drugi manipulatori ljudima „otkrivaju“ buduće događaje bez ikakvih argumenata i stvarnog znanja. Tek sa ovim realiziranim predznacima, na temeljima islamskih pouzdanih izvora, otkrivaju se lažna predviđanja raznih svjetskih demagoga čije najave nisu bile utemeljene na znanju, nego na neznanju i nesigurnim izvorima.

- Poznavanje ovih događaja i njihovih detalja, a posebno kada budemo svjedoci njihovog pojavljivanja, povećava i učvršćuje naše vjerovanje. Dosadašnji nagoviješteni i ostvareni simptomi Kijametskog dana izvanredan su dokaz istinitosti Allahove vjere i njene originalnosti.

- Poznavanjem detalja nekih predznaka Smaka svijeta, razumijevamo i pravilno shvatamo i neke šerijatsko-pravne propise. Tako, primjera radi, u vjerovjesničkim predskazanjima o Dedždžalu i njegovom boravku na Zemlji se govori da će dan trajati poput godine, a onda poput mjeseca, pa su ashabi pitali Vjerovjesnika, s.a.v.s., da li će biti dovoljno obaviti taj dan samo pet dnevnih namaza kada dan bude toliko trajao, kao što ih mi obavljamo u ovim našim danima. Allahov Poslanik, s.a.v.s., je odgovorio da, kada se to desi, onda će se računati. Iz ovakvih predanja o posljednjim dunjalučkim danima, pojavi Dedždžala i tolikom trajanju dana i noći, islamski učenjaci su izvukli propis za namaz onih stanovnika zemlje gdje dan i noć traju neobično dugo. ${ }^{10}$

Naravno, iz poznavanja predznaka Smaka svijeta moglo bi se još iznjedriti veliki broj poruka i koristi, ali i ovo je dovoljno da se spozna koliko je značajno biti upućen u ovaj fenomen i sve detalje koji će mu prethoditi.

\section{Vrste predznaka Smaka svijeta}

Većina islamskih autora predznake Smaka svijeta dijele na dvije osnovne vrste: male i velike.

Male predznake definiraju kao predznake koji će se odigrati prije deset velikih predznaka. Oni se pojavljuju prije Smaka svijeta na duži vremenski period i uobičajene su prirode. ${ }^{11}$ Međutim, neki autor male

${ }^{10}$ O ovim koristima i konkretnim porukama, pogledaj: Kraj svijeta, str. 5-8.

11 Vidi: Fuad Sedić, Mali predznaci Sudnjeg dana, str. 15. 
predznake Kijametskog dana dijele na davne i trajne, koje neki nazivaju srednjim predznacima.

Davni predznaci, po ovoj definiciji, su oni koji su se davno pojavili i okončali, a nazivaju se malim predznacima zato što su se davno desili i što između njih i stvarnog Smaka svijeta postoji dug vremenski interval, kao što je najava poslanstva Muhammeda, s.a.v.s., njegova smrt, rascjepljenje Mjeseca, pojava ogromne vatre u Medini i sl.

Srednji ili trajni predznaci su oni znakovi koji su se pojavili, ali se nisu završili i okončali, nego još traju, pa čak se i uvećavaju. Ovi predznaci su mnogobrojni. Među njima je pojava lažljivaca, povjeravanje vodstva nedostojnim, pojava razvrata i nemorala, mnoštvo ubistava, učestalost zemljotresa i drugih prirodnih nepogoda i dr.

Veliki predznaci Smaka svijeta definiraju se kao velike i neobične stvari koje će se pojaviti pred samo nastupanje ovog fenomena. Kada se oni počnu realizirati, onda možemo očekivati veoma brzo nastupanje Kijametskog dana. To su, ustvari, neobični fenomeni koji će se manifestirati jedan za drugim, kao što se biseri nižu u nisku bisera. Allahov Poslanik, s.a.v.s., je spomenuo deset znakova, nakon kojih će Smak svijeta neodložno nastupiti i nabrojao ih je: Dim, Dedždžal, životinja, izlazak Sunca sa zapada, silazak Isaa, a.s., sina Merjeminog, pojava Je'džudža i Me'džudža, tri propadanja u zemlju - jedan na istoku, jedan na zapadu i jedan na Arapskom poluotočju, a zadnji predznak je vatra koja će izaći iz Jemena tjerajući ljude prema mabšreru - sastajalištu. ${ }^{12}$

\section{Mali predznaci Smaka svijeta}

Neki autori su, na temelju autentičnih hadisa Allahovog Poslanika, s.a.v.s., nabrojali preko stotinu simptoma malih predznaka Smaka svijeta. ${ }^{13}$ Mi ćemo u ovom radu spomenuti samo fenomen učestalosti zemljotresa kao jedan od najavljenih malih predznaka Smaka svijeta.

Allahov Poslanik, s.a.v.s., nagovještava ovaj fenomen u više vjerodostojnih hadisa. Navedimo neke:

\footnotetext{
12 Hadis bilježi Muslim u Sahibu.

13 Muhammed ibn Abdurrahman el-Arifi u svom djelu o ovom fenomenu navodi čak 131 mali predznak Smaka svijeta. (Vidi: Kraj svijeta, str. 25-29).
} 
„Né́e nastupiti Kijametski dan dok se ne podigne znanje, ne budu uŕestali zemljotresi, ne nestane bereketa u vremenu, ne pojave brojne smutnje, ne umnože ubistva i ne raširi bogatstvo." 14

„Pred Kijametski dan će se pojaviti velika smrtnost, nakon koje će uslijediti ǔestali zemljotresi. " 15

Abdullah b. Havale, r.a., prenosi: „Allahov Poslanik, s.a.v.s., stavio je ruku na moju glavu, pa rekao: „Sine Havalov, kada vidiš međusobna razmimoilaženja na Svetim mjestima, znaj da su se približili zemljotresi, nesreće $i$ ogromne teškoće. Tada će nastupanje Sudnjeg dana biti bliže ljudima nego što su moje ruke blizu tvoje glave!" 16

„Moj ummet je ummet milosti, ra njega nema karne na abiretu. Allab je učinio da ubistva, remljotresi $i$ smutnje budu njihova kazna na ovome svijetu. " 17

Nauka tvrdi da zemljotres nastaje kao posljedica dejstva unutrašnjih sila, tektonskih pokreta i poremećaja u Zemljinoj kori, vulkanskih erupcija ili pomicanjem stjenovitih masa iz viših u niže planinske dijelove, ${ }^{18}$ što uopće ne oponira Vjerovjesnikovim, s.a.v.s., predanjima, jer očito je da se te tektonske ploče aktiviraju ljudskim griješenjem, velikim nemoralom, upotrebom kamate i drugim anomalijama.

Od prošlog stoljeća zemljotresi su česta pojava u svijetu. Zabilježeni su veliki zemljotresi u Tokiju i Jokohami, u Japanu, 1923. godine sa 99.000 poginulih; u Mesini, Italija, 1908. godine, sa 160.000 poginulih; u Kansu, Kina, 1920. godine, sa 180.000 poginulih; u NanŚanu, Kina, 1927. godine, sa 200.000 poginulih i u Tangšanu, Kina, 1976. godine, sa 655.000 poginulih. ${ }^{19}$

Najjači zemljotres u XXI stoljeću desio se u decembru 2004. na zapadnoj obali Sjeverne Sumatre. 227.898 ljudi je poginulo ili se smatra nestalima, a 1,7 miliona ljudi je ostalo bez domova zbog zemljotresa i „cunamija“ koji je nakon njega uslijedio. Cunami je tada pogodio četrnaest zemalja u Južnoj Aziji i Istočnoj Africi.

\footnotetext{
${ }^{14}$ Hadis bilježe Buhari, Muslim, Ibn Madže i Ahmed.

${ }^{15}$ Hadis bilježe Ahmed, Ibn Hibban, Hakim, Taberani, Bezzar i Ebu Ja'la a ocijenjen je kao sahih.

16 Hadis bilježe Ebu Davud i Ahmed a ocijenjen je kao sahih.

${ }^{17}$ Hadis bilježe Ebu Davud, Ibn Madže, Ahmed i Hakim i ocijenjen je kao sahih.

18 Pogledaj: Mala enciklopedija, Prosveta, Beograd, 1978, 1/661.

${ }^{19}$ Uporedi: Sva cuda svijeta, str. 423.
} 
Riječ „cunami““ je japanskog porijekla i znači okrutni i razorni morski valovi. Nazvan je tim imenom jer se ta vrsta potresa često javlja u blizini Japana. „Cunami“ se ponekad naziva i "morskim podrhtavanjem", a morski talasi koji nastanu kao posljedica takvog podrhtavanja dosežu visinu od nekoliko desetina metara i uništavaju velika obalna područja na koja udare svom svojom silinom, posebno onda kada ispred njih ne postoji nikakva prirodna brana koja bi ih ublažila.

Posljedica tih silovitih potresa unutar okeana su džinovski vodeni talasi koji napadaju morsku obalu brzinom koja ponekad doseže i 750 $\mathrm{km}$ na sat u visini od 30 do 40 metara, udarajući na jedan kvadratni metar obale snagom od oko 100 hiljada tona vode, nanoseći tako mnogo veću štetu nego što su posljedice samog potresa, s obzirom na ogroman pritisak i snagu vode.

Nisu samo zemljotresi uzročnici „cunamija“ (ali su najčešći), tu su i tektonska slijeganja, vulkanska aktivnost i pad nekih svemirskih tijela kao što su meteori.

Najveći „cunami“ koji poznaje savremena ljudska povijest jeste onaj koji se desio 5. juna 1869. godine koji je, kao posljedica podrhtavanja morskog dna Japanskog kanala, pogodio istočnu obalu japanskog ostrva Honšu. Talas visok trideset metara potpuno je zbrisao cijela sela, uništio više od 10 hiljada domova i usmrtio oko 26 hiljada ljudi. Talasi tog „cunamija“ krenuli su istočno preko Tihog okeana do ostrva Hilo na Havajima, potom su krenuli ka obali SAD-a od koju su se odbili i udarili u obale Novog Zelanda i Australije.

Zemljotresi i vulkani su velika Allahova znamenja za Njegova stvorenja, u kojima vjernici opažaju posebnu imansku dimenziju. U islamskim izvorima navodi se da će uzrok učestalosti zemljotresa biti kamata i njena velika upotreba, kao i velika anarhija. ${ }^{20}$

Alija b. ebu-Talib, r.a., rekao je: „Svaka kazna uslijedi isključivo poslije grijeha, a otklanja se jedino pokajanjem (tevbom). "Svi kur'anski ajeti o kazni objavljeni su kao odgovor na ljudske grijehe. Jedan od najupečatljivijih kur'anskih ajeta koji govori o zemljotresima nalazi se u suri En-Nahl, 26. ajet, u kojem naš Uzvišeni Gospodar kaže: „I oni prije njih su spletkee pleli, pa je Allah iæ temelja zgrade njihove porušio, i krov se na njib srušio - stigla ib je kazna odakle nisu očekivali. "

${ }^{20}$ Vidi: El-Gimari, Mutabekatu-l-ibtira' ati-l-'asrijje lima abbere bibi Sejjidu-l-berijje, str. 105. 
Zar je moguće naći precizniji opis zemljotresa od ovog kur'anskog, a uistinu je mnogo ajeta koji govore o kažnjavanju neposlušnih Allahovih, dž. š., robova.

Općenito gledajući, sve kosmičke pojave poput zemljotresa, vulkana i uragana jesu dio Allahove, dž. š., vojske podčinjene, kao kazna za neposlušne, iskušenje za poslušne i opomena za spašene. Takve pojave ne možemo poimati na način da mi možemo njima ovladati ili ih odvojiti od toga da one jesu dio Allahove, dž. š., vojske.

Često se kaže da su zemljotresi Allahova kazna zbog čovjekovog nereda i opomena drugima. Zanimljivo mišljenje ima Miroljub Petrović, koji je u TV-emisiji „Na rubu znanosti“ rekao da su, u posljednje vrijeme, dva najveća zemljotresa pogodila Japan, zbog toga što se u njemu nalazi procentualno najveći broj ateista, a Haiti zbog toga što se u njemu nalazi najveći broj satanista na svijetu.

Zanimljivo da naučnici tvrde da se to dešava pokretanjem tektonskih ploča, ali i pored svih savremenih sprava nisu u stanju predvidjeti ovaj fenomen, što svakako upućuje na nepoznanicu koju je Allah ostavio kao Svoj „,bič“ neposlušnim robovima. Jednima je to kazna zbog nevjerovanja, ateizma i satanizma, a drugima oprost od grijeha i spašavanje od Vatre na Sudnjem danu.

Vjerniku su ove nesreće otklanjanje grijeha i sankcija na Sudnjem danu. Kolika je Allahova milost spram muslimana, najilustrativnije oslikava posljednji hadis u kojem se kaže da će muslimani sa iskušenjem smutnje, ubistava i zemljotresa svoju kaznu već pretrpjeti na ovome svijetu i ona će ih očistiti od grijeha i kazni onoga svijeta. Nevjernici će iskusiti i ovozemaljsku, prolaznu, ali i onosvjestsku vječnu kaznu, tako da sva iskušenja, muke i belaje koje dožive na ovome svijetu neće nimalo umanjiti njihovu kaznu na onome svijetu.

Kako nam samo naš Poslanik, s.a.v.s., odašilje signal nade. Kako je to lijepo čuti. Pa zar da ne budemo ponosni što smo muslimani?! Zar ne izdržati još malo ova iskušenja, prije vječnog uživanja i onosvjetskog blagostanja?!

\section{Veliki predznaci Smaka svijeta}

Već smo spomenuli deset velikih predznaka Smaka svijeta koji će se nizati jedan za drugim. Sve će to biti fenomeni koji će ljudima 
posebno zaokupiti pažnju. To će, ustvari, biti posljednja upozorenja ljudima na kraj ovog svijeta i poziv na njihovo konačno pokajanje.

Jedan od ovih predznaka je pojavljivanje čudne životinje koja će govoriti ljudima i koja će razotkrivati koji od njih su vjernici, a koji nevjernici. Vjerovjesnik, s.a.v.s., je spomenuo ovu tajanstvenu životinju u više autentičnih predanja. Neke od njih ćemo navesti u nastavku teksta.

„Poそ̌urite sa dobrim djelima prije šestero: prije įlaska sunca sa zapada, prije

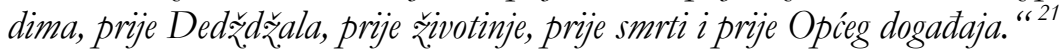

„Prvi predznak Sudnjeg dana koji će se pojaviti je iælazak Sunca sa zapada $i$ iqlazak vivotinje medu ljude. "22

„Zaista je prvi predznak koji ce se pojaviti: izlazak sunca sa zapada $i$ izlazak životinje pred ljude u jutarnjem vremenu. Bilo koji od ova dva predrnaka da se prvi dogodi neposredno poslije njega cé uslijediti drugi. "23

„Troje kad iqade tada crovjeku neće biti od koristi to sto će tada vjerovati, ako prije nije vjerovao ili ako nije, kao vjernik, kakvo dobro uradio: įlazak sunca sa

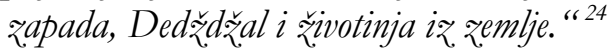

„Pojavit će se životinja iz zemlje s kojom će biti Sulejmanov pečat i Musaov stap, pa će na vjernikovo lice staviti bijeli biljeg a nevjernikov nos pečatom popečatiti. Ljudi će se okupiti, pa će ovaj onome govoriti vjerniče, a onaj ovome nevjerniče. " 25

Očito je da će Uzvišeni Allah pred sami kraj ovoga svijeta poslati jednu posebnu životinju koja će ljudima govoriti i upozoravati ih na ono što nije dobro. ${ }^{26}$ To je zbog toga što će se, u tom vremenu, ljudima razni harami činiti normalnim $i$ što će u prakticiranju raznovrsnih harama učestvovati i iskreni vjernici, zajedno sa dokazanim nevjernicima i licemjerima.

$\mathrm{Na}$ žalost, u vjerodostojnim hadisima Allahovog Poslanika, s.a.v.s., nema više detalja vezano za ovu životinju koja će biti jedan od prvih velikih predznaka Kijametskog dana. Upravo zbog toga postoje razilaženja među islamskim učenjacima gdje će ta životinja izaći. Jedni tvrde da će izaći iz brežuljka Safa u Mekki, dok drugi smatraju da će

\footnotetext{
${ }^{21}$ Hadis bilježe Muslim i Ahmed.

${ }^{22}$ Hadis bilježi Muslim.

${ }^{23}$ Hadis bilježe Muslim, Ebu Davud, Ibn Madže, Ahmed i Tahavi.

${ }^{24}$ Hadis bilježe Muslim i Tirmizi.

${ }^{25}$ Hadis bilježe Tirmizi, Ibn Madže i Ahmed i ocijenjen je kao hasen.

${ }^{26}$ Uporedi: Dr. Omer Sulejman el-Eškar, El-Kijametu-s-sugra, str. 286.
} 
pojaviti ispod Kabe, treći u Jemenu, a četvrti vjeruju da će se pojaviti iz pustinje. $^{27}$

Neki autori klasičnih djela daju joj zanimljiva i čudna svojstva, pa kažu da će imati glavu vola i uši slona, a neki smatraju da će to, ustvari, biti Salihova, a.s. kamila koju je njegov narod zaklao. Neki tvrde da se radi o mladunčetu Salihove, a.s., kamile. Imam Kurtubi smatra ovo mišljenje najispravnijim. ${ }^{28}$

Neki smatraju da je to životinja Džessasa, spomenuta u hadisu Temim ed-Darija, r.a., u kazivanju o Dedždžalu. Nazvana je Džessasom jer je krijumčarila vijesti o Dedždžalu. ${ }^{29}$

Ima ih koji misle da je to zmija okačena na zid Kabe koju je ElIkab strgao kad su Kurejšije htjele sagraditi Kabu.

Jedni su mišljenja da je Dabbetun - životinja, zbirna imenica za sve što puže zemljom. Nije riječ ni o kakvoj čudnovatoj i neuobičajenoj životinji.

Ima i onih koji pretpostavljaju da se možda mislilo na bakterije koje opasno razaraju ljudsko tijelo i zdravlje.

Ako analiziramo brojne komentare Kur'ana, naići ćemo na različite opise ove životinje - da joj je glava poput glave vola, oči poput očiju svinje, uši kao u slona, rogovi kao u jelena, vrat poput vrata noja, grudi kao u lava, boja kože kao u tigra, struk kao u mačke, rep kao u ovna, noge kao u deve, da je šezdeset aršina duga, da ima perje, kopito i bradu! ${ }^{30}$

Naime, prema najvećem broju islamskih učenjaka, očito je da se radi o životinji, jer je to eksplicite navedeno u Kur'anu. Allah Uzvišeni o tome kaže: „I kada dođe vrijeme da oni budu kažnjeni, Mi ćemo učiniti da iz. zemlje izide jedna životinja koja će im kaz̧ivati da ljudi u dokaze Naše nisu bili uvjereni" 31

Ono što je posve jasno je da će ova životinja izaći pred sami Kijametski dan, nakon što ljudi ogreznu u grijehu, neposlušnosti Allahu,

\footnotetext{
27 Pogledaj: El-Kě̌šaf, 3/371.

28 Pogledaj njegovu elaboraciju ovog fenomena: El-Džami'u li abkami-l-Kur'an, 13/243-248.

${ }^{29}$ Uporedi: Ez-Zamahšeri, El-Keššaf, 3/371.

30 Vidi o tome: Ez-Zamahšeri, El-Kešsaf, 3/371 i Sejjid Kutb, U okrilju Kur'ana, 20/26-27.

${ }^{31}$ En-Neml, 82.
} 
nakon afirmiranja zla, devalviranja dobra, nakon pojave razvrata i nakon što prevladaju smutnje i anarhija. ${ }^{32}$

Dakle, kako vidimo u ovom ajetu, potpuno je jasno da će životinja govoriti ljudima i iznositi im jasne i nedvosmislene dokaze. Tako Ibn Džurejdž prenosi od Ibnu-z-Zubejra, r. a, da će životinja reći: „O ti, taj $i$ taj, budi radostan, ti si jedan od stanovnika Dřenneta!, a zatim: O ti, taj i taj, ti si stanovnik Vatre!"33

U jednom predanju od Imama Ahmeda i Tirmizije spominje se da će ova životinja stavljati biljege na ljude, tako da će se znati ko je vjernik, a ko nevjernik. Naime, ona će izaći sa Musaovim, a.s., štapom i Sulejmanovim, a.s., prstenom, pa će žigosati nos nevjernika sa tim prstenom. Lice vjernika dodirnut će štapom, tako da će ljudi, kada sjednu za sofru, jedni drugima reći: „O vjerniče!“", odnosno: „O nevjerniče! “34, jer će na njihovom čelu, nakon dodira ove životinje, pisati: „Vjernik ili Nevjernik"!

Ustvari, kada dodirne vjernika, njegovo lice će blistati i to će biti znak njegovog imana, dok će nevjerniku utisnuti prsten, tj. pečat na njegov nos i to će biti znak njegovog nevjerstva. ${ }^{35}$

Čak ima i onih koji smatraju da će to zapravo biti čovjek koji će ljudima donositi dokaze protiv njih. Oni, naime, pretpostavljaju da je životinja insan koji će polemisati sa sljedbenicima novotarija i kufra ne bi li prestali, pa će svako propasti ili biti spašen nakon što je upoznat sa Istinom. Ovo mišljenje spominje i Kurtubi u svom tefsiru, ali ga odbacuje. Da je životinja čovjek, koji raspravlja sa sljedbenicima novotarija, onda u tome ne bi bilo neprirodnosti i to ne bi bio jedan od deset velikih predznaka Sudnjeg dana. ${ }^{36}$

Nužno je vjerovati kako će Allah dž. š. na kraju vremena ljudima poslati životinju iz zemlje koja će razgovarati sa njima. Njen govor će im biti jasan dokaz kako su, zbog njihovog poricanja Allahovih znakova, zaslužili ispunjenje prijetnje. Kada životinja izađe, ljudi će shvatiti kako je

\footnotetext{
32 Vidi: Tefsir Ibn Kesira (na bosanskom), str. 984 i Muhammed Ali es-Sabuni, Safvetu-ttefasir, $11 / 22$.

33 Ibn Kesir, Tefsir, str. 985 i Ez-Zamahšeri, El-Kěšsaf, 3/371.

34 Vidi o tome: El-Benkani, Ešratu-s-sa'ati-l-kubra, str. 198; El-Arifi, Kraj svijeta, str. 289 i El-Vabil, Predznaci Sudnjeg dana, str. 258.

35 Vidi: El-Kě̌šaf, 3/372.

36 Uporedi: El-Džami'u li abkeami-l-Kur'an, 13/247.
} 
to jasna natprirodna opomena o blizini Sudnjeg dana. Prije toga nisu vjerovali u Allahove ajete niti u Obećani dan.

Hasan el-Basri smatra da će ova tajanstvena životinja izlaziti iz Zemlje tri dana. Alija b. ebi-Talib, r.a., isto smatra da će ona izlaziti tri dana i da će se za ta tri dana samo trećina te životinje pojaviti. Neki smatraju da će joj se samo pojaviti glava koja će dosezati do oblaka ili čak do nebesa. ${ }^{37}$

Zamahšeri navodi predanje da će se ova čudnovata životinja pojaviti dok Isa, a. s, bude sa muslimanima obavljao tavaf oko Kjabe. Dok oni budu u tavafu, Zemlja će puknuti i iz Safe, u blizini Kjabe, pojavit će se ova životinja. ${ }^{38}$

Spominjanje životinje u suri En-Neml jača mišljenje kako je riječ o životinji koja ima moć govora sa ljudima. Upravo u ovoj suri En-Neml se spominje razgovor između insekata, ptica, džina i Sulejmana a.s. Spominjanje životinje je došlo u odgovarajućoj harmoniji sa surom. ${ }^{39}$

Ahmed Šakir kaže: „Ajet je jasan, riječ je o arapskoj imenici (dabbetun) rije je značenje poznato $i$ jasno $u$ arapskom jeqiku $i$ nema nikakve potrebe za odstupanjem u značenju (...) Brojni hadisi u Sabibima i drugim zbirkama govore o životinji kao predznaku koji će se pojaviti na kraju vremena. Zabilję̌rene su i brojne vijesti koje nisu direktno vezane za Vjerovjesnika, s.a.v.s. - dostavljača Objave $i$ komentatora Knjige - pa zasto bi sve to ostavili?!

Međutim, naši pojedini savremenici, pripadnici islama u kojima se proširila nevaljalost govora i mišljenja, ne ̌̌ele vjerovati u gajb (nevidljivo), ne žele preći granicu materije koju su im racrtali njihbovi uritelji $i$ uzori, nevjernici idolopokloničke raskalašene Evrope, otpadnici od svib ljudi i vjera, oni ne mogu vjerovati u ono u šta mi vjerujemo niti to mogu jasno poreći, nego samo umotavaju govor, raspravljaju $i$ petljaju a zatim izokrécu smisao riječi od njenog ispravnog značenja čneći ib tako sličnijim znakovima nego onom što oni poriču i kriju duboko u sebi. "40

Na kraju, treba reći da je pojava životinje i njeno obraćanje ljudima fenomen koji treba da se razlikuje od onih običnih pojava u našem životu. Zar svi veliki predznaci nisu upravo fenomeni koji će ljudima zaokupiti maštu i ukazati im na nešto što je, do kraja, važno?

\footnotetext{
37 Zanimljive navode donosi Zamahšeri: El-Keššaf, 3/371.

38 El-Kešsaf, 3/372.

${ }^{39}$ Vidi: Fi zilali-l-Kur'an, 5/2667

${ }^{40}$ Komentar na Musned Ahmeda, 15/82
} 
Zar fenomen pojave Dedždžala nije nešto sasvim posebno: njegov izgled, njegovo ponašanje i nadnaravne moći koje će ljudima demonstrirati?! Zar pojava Isaa, a.s., nije nešto posebno zanimljivo, čudno i neobično?! Zar pojavljivanje i izlazak Sunca sa zapada ne predstavlja fascinantnu i čudnu pojavu o kojoj ljudi ni sanjali nisu?!

Otuda i pojavljivanje ove životinje i njen govor upućen ljudima treba da bude poseban čin i jedan od događaja koji treba da usredsrede čovjeka na posebno razmišljanje o njemu i njegovoj svrsi bitisanja na ovome svijetu.

Ako mogu da iskažem i svoje skromno mišljenje, onda smatram, pored svih ostalih pouka i poruka slanja ove životinje, da će ona svojim dolaskom i kritikom upućenom onim ljudima koji su zapostavili vjeru u Allaha i ostavili prakticiranje Njegovih propisa, ustvari poniziti, minimizirati i devalvirati grješnike i nevjernike toga vremena, jer će ona životinja - biti svjesnija od njih. Ona je svjesna Allaha i Njegove moći, a ljudi kojima je Allah dao moć govora, razmišljanja, analizirana i meditiranja - bit će na nižem stepenu od nje!

Ovim će se samo zorno pokazati kako čovjek može biti i gori od životinje, kao što Allah konstatira u Svojoj Knjizi: „Mi smo za Dřehennem mnoge ď̃ine i ljude stvorili: oni pameti imaju - a njima ne shvaćaju, oni oř imaju a njima ne vide, oni uši imaju - a njima ne čuju: oni su kao stoka, čak i gori - oni su, zaista, nemarni!" 41

Zanimljivo je, na kraju, spomenuti razmišljanje Ibn Hadžera elAskalanija. Naime, on smatra da će se ova misteriozna životinja pojaviti $\mathrm{u}$ istom danu kada i izlazak Sunca sa zapada. Njegov zaključak je da će izlaskom Sunca sa zapada čovjeku biti onemogućeno da se pokaje, pa će životinja koja će stavljati pečat na čelo svakog čovjeka, ustvari, pokazati ko je pokajnik, a ko grješnik, jer će na svakom od njih pisati: „Vjernik ili Nevjernik! " 42

\section{Zaključak}

Nakon analiziranja brojnih autentičnih hadisa koji se bave sa ovim fenomenom, a koji eksplicite govore o trijumfu islama i muslimana, zaključak je da se ne smijemo pasivizirati, uspavati, ulijeniti i čekati te

\footnotetext{
41 Al-A'raf, 179.

42 Vidi: Bliqina pojave Mehdije, str. 139.
} 
trenutke bez našeg angažmana na planu ispravnog interpretiranja Allahove vjere.

Bez ulaganja našeg maksimalnog truda, bez davanja svega od sebe, bez istrajnog rada na svim poljima našeg života i pokušaja ispravljanja negativnosti i afirmiranja dobra - ne možemo se ni nadati Allahovoj pomoći!

Ove vijesti o trijumfu islama i muslimana treba samo da ojačaju naše slabe strane, da preuzimajući iskustva iz ostavštine i baštine naših predaka doprinesemo afirmiranju istinskih vrijednosti i ljepota.

Vjerovjesnik, s.a.v.s., je obećao trijumf muslimana, ali on se neće realizirati sve dok su muslimanski narodi ovako zaostali, podijeljeni, nemoćni, lijeni, izgubljeni, pasivizirani i međusobno neprijateljski raspoloženi!

Neophodno je da islamski aktivisti, reformatori i da'ije, bez obzira na određene razlike, nađu modalitete međusobne suradnje, kako bi se Ummet iznutra promijenio, transformirao i aktivirao sve svoje potencijale. Muslimani trebaju naći mehanizme sa kojima će nadoknaditi propušteno u posljednjih nekoliko stoljeća i sustići napredni svijet, apsorbirajući od njega ono što je dobro i pozitivno, dajući mu ono što on nema od svojih vrednota i ljepota!

Možemo primijetiti da su ashabi Allahovog Poslanika, s.a.v.s., bili nesumnjivo uvjereni da će im Allah pomoći, da će njihove vojske izvojevati pobjede, kako je Allah i obećao, ali ovo ubjeđenje ih nije spriječilo da marljivo rade $\mathrm{i}$ da se maksimalno pripremaju za te borbe, ali i da se do kraja angažiraju u svim segmentima života.

Analizirajući autentične hadise koji govore o fenomenu Smaka svijeta, pored onih zabrinjavajućih i zastrašujućih, nailazimo i na veliki broj onih hadisa koji nagovještavaju trijumf islama i muslimana.

Poznavanje i prezentiranje ovakvih autentičnih predanja značajno je zbog slijedećih razloga:

- zato što se ovim predskazanjima pokazuje da će na kraju svijeta biti olakšanje za islam i muslimane, kao što je, u biti, i islamski princip: „Olakšsavajte, a nemojte otežavati, i obradujte a nemojte rastjerivati!“

- zato što muslimani, kroz nepravdu, nasilje i tiraniju nad njima u posljednjih nekoliko stoljeća, osjećaju gorčinu i neku vrstu bezizlazne 
situacije. Ukoliko bi se nastavilo sa ovakvim osjećanjem ogorčenosti i nemoći, uništit će u sebi ambicije, odlučnost i aspiracije za promjenama i pokušajem transformacije sebe i društva. Otuda ovakve Vjerovjesnikove, s.a.v.s., najave trijumfalnih uspjeha koje će muslimani imati na samom kraju ovog dunjalučkog putovanja. Te najave su vjetar u leđa islamskom ummetu i velika motivacija da se sva iskušenja stoički i strpljivo podnesu, da barjak islama hrabro čuvaju i dostave generacijama nakon njih,

- zato što brojni pojedinci i grupe u svijetu vode psihološki rat protiv islama i muslimana, imputirajući im ekstremizam, fundamentalizam i terorizam, čime im ubijaju nadu u bolje sutra i želju za svjetlijom budućnošću. Zbog toga je izuzetno značajno širiti ovakve vjerodostojne hadise koji nagovještavaju trijumf islama, čime će se ispuniti srca muslimana takvim zrakama koje će uništiti tamu očaja, maglu nemoći i oblake besperspektivnosti,

- zato što je među brojnim vjernicima proširena pogrešna i deprimirajuća predstava o kraju dunjaluka ili budućnosti ummeta, potpuno crna slika koja se temelji samo na tretiranju smutnji, nesporazuma i međusobnom sukobu muslimana.

Zaključak je da treba širiti ove radosne vijesti koje su najavljene kur'anskim i sunnetskim tekstovima ili su već viđene u povijesti. Mnogo toga smo imali prilike saznati preko Poslanikovih, s.a.v.s., hadisa i njegove časne biografije, gdje je i najveće iskušenje bilo prevladano Vjerovjesnikovom, s.a.v.s., vjerom u bolju budućnost i sretan završetak svih stvari.

Osobine stalnog afirmiranja nade i sretnog završetka pokazivali su brojni islamski velikani kroz povijest. Tako Hasan el-Benna na jednom mjestu kaže: „Činjenice današnjice su snovi prošlosti, a snovi današnjice su činjenice sutrašnice! " 43

\section{Literatura:}

1. El-Kur'ani-l-kerim, prijevod: Besim Korkut, Medina, S. Arabija, 1412. h. g.

2. Ahmed, b. Hanbel eš-Šejbani: El-Musned, El-Mektebu-l-islami, Bejrut, 1983.

3. El-Albani, Muhammed Nasiruddin: Sabibu-l-džami'i-s-sagiri ve zijadetubu, ElMektebu-l-islami, Bejrut-Damask, 1988.

${ }^{43}$ Dr. Jusuf el-Karadavi, Radosne vijesti o trijumfu islama, str. 12. 
4. El-Albani: Silsiletu-l-ehadisi-s-sahiha, Mektebetu-l-me'arif, Rijad, 1995.

5. El-'Arifi, Muhammed ibn Abdurrahman: Kraj svijeta, Udruženje za promociju i afirmaciju mladih intelektualaca PAMI, Sarajevo, 2011.

6. El-Benkani, Ebu Enes Madžid: Ešratu-s-Sa'ati-l-kubra ve deliluba mine-l-Kur'ani ve sabihi-s-Sunneti-n-nebevijjeti, Mektebetu 'Ibadu-r-Rahmani i Mektebetu-l-'ulumi ve-1hikemi, Egipat, 2006.

7. El-Buhari, Muhammed b. Isma'il: Buharijeva zbirka hadisa, prijevod i komentar: grupa prevodilaca, Visoki saudijski komitet za pomoć BiH, Sarajevo, 2009.

8. El-Buhari: Es-Sahih, Daru ihjai-t-turasi-l-'arebi, Bejrut, bez god. izdanja.

9. Ebu Davud, Sulejman es-Sidžistani: Es-Sunen, Daru ihjai-s-sunneti-n-nebevijjeti, bez mjesta i god. izdanja.

10. El-Eškar, dr. Omer Sulejman: El-Kijametu-s-sugra, Mektebetu-l-felah, Kuvajt, 1988.

11. El-Gimari, Ahmed b. Muhammed el-Haseni: Mutabekatu-l-ibtira'ati-l-asrijje lima abbere bihi Sejjidu-l-berijje, Daru-l-Kahire, Kairo, 2000.

12. El-Hakim, Ebu 'Abdullah en-Nejsaburi, El-Mustedreku 'ale-s-sabihajni, Daru-1-fikr, Bejrut, 1978.

13. Ibn Hibban, Muhammed el-Busti, Es-Sahih, Mu'essesetu-r-risale, Bejrut.

14. El-Karadavi, dr. Jusuf, Radosne vijesti o trijumfu islama, s arapskog: Hajrudin Hodžić, Muslimansko Bratstvo, Sarajevo, 2004.

15. Ibn Kesir, Isma'il: Tefsir, Visoki saudijski komitet za pomoć BiH, Sarajevo, 2002.

16. El-Kurtubi, Muhammed b. Ahmed: El-Džami'u li abkami-l-Kur'an, Daru-l-hadis, Kairo, 1996.

17. Kutb, Sejjid: U okrilju Kur'ana, FIN, Sarajevo, 1997.

18. Ibn Madže, Muhammed el-Kazvini: Es-Sunen, Daru-1-hadis, Kairo, 1994.

19. Mala enciklopedija, Prosveta, Beograd, 1978.

20. Muslim, b. Hadždžadž en-Nejsaburi: Es-Sahih, Daru Ibn Hazm, Bejrut, 1995.

21. Muslimova zbirka hadisa, prijevod: Š. Kurdić, Kúca mudrosti, Zenica, 2003.

22. En-Nesai, Ebu 'Abdurrahman: Es-Sunen, Daru-1-fikr, Bejrut, bez god. izdanja.

23. Es-Sabuni, Muhammed Ali: Safvetu-t-tefasir, Daru-1-Kur'ani-1-Kerim, Bejrut, 1981.

24. Sedić, dr. Fuad: Mali predžnaci Sudnjega dana, AIO, 1996. (bez mjesta izdanja).

25. Sva únda svijeta - vodic kroz najvé́e prirodne liepote, s engleskog: Tamara Levak Potrebica, Mozaik knjiga, Zagreb, 2004.

26. Et-Tahavi, Ebu Dža'fer Ahmed b. Muhammed, Šerbu Méani-l-asar, Daru-l-kutubi-1'ilmijje, Bejrut, 1996. 
27. Tirmizi, Ebu 'Isa Muhammed b. 'Isa, El-Džami'u-s-sahih, Daru-l-kutubi-1-'ilmijje, Bejrut, 1987.

28. Timiqijina zbirkea hadisa, prijevod: prof. Mahmut Karalić, Elči Ibrahim-pašina medresa, Travnik, 2000.

29. Al-Wabil, Yusuf: Predznaci Sudnjeg dana, s arapskog: Rasim Brković i Senad Ćeman, Bemust, Sarajevo, 2001.

30. Ez-Zamahšeri, Ebu-1-Kasim: Tefsiru-l-keš̌saf, Daru-l-kutubi-l-'ilmijje, Bejrut, 2003. 
Šefik Kurdić, PhD

\section{ISLAMIC PERCEPTION OF THE END OF THE WORLD PHENOMENON}

\section{ABSTRACT}

End of the world or the Last Day was and still is a phenomenon that has inspired the imagination of many people in all generations, especially in recent times, when this issue was actualised by the media .

Many have been referring to the ancient Mayan calendar, which claims that the world ends on 21st December of 2012. People understood that on that same day the End of the World will occur, so this article is a contribution to a better understanding of this phenomenon. This text treats the mentioned phenomenon and its Islamic perception, with a few important details that try to explain it better to a buman perception. Article also mentions a fundamental division of this phenomenon symptoms and cites one example of a small and large sign of the Judgement Day.

Key words: end of the world, little signs, large signs. 


\section{الأستاذ الدكتور شفيق كورديتش}

\section{نظرة الإسلام إلى ظاهرة "يوم القيامة"}

\section{الخلاصية}

كانت ولا تزال ظاهرة يوم القيامة أو انتهاء الدنيا تثير خيال الكثيرين في كل الأجيال، وخاصة في الآونة الأخيرة عندما تم ترويج هذه الظاهرة إعلامياً بشكل كبير.

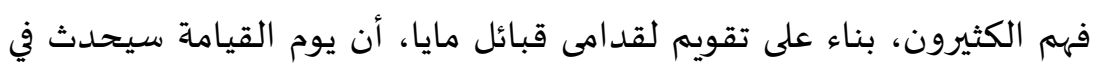

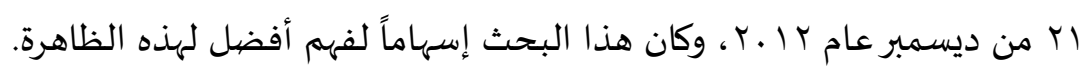

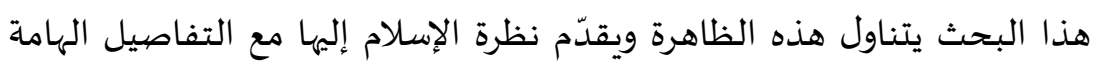

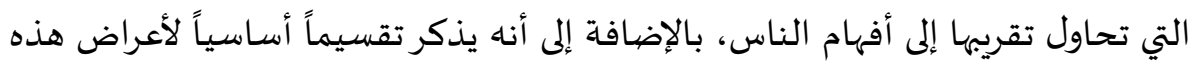

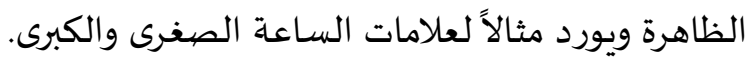

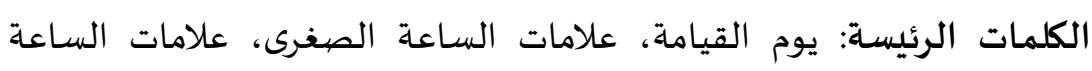
الكبرى 